\title{
Business Process Management: Today and Tomorrow
}

\author{
Paul Harmon \\ BPTrends, USA \\ pharmon@sbcglobal. net
}

Companies have been striving to improve their business processes for decades, but, in the past few years, the emergence of a variety of new software technologies and the relentless competitive pressures on large companies to outsource and to develop a worldwide presence has taken the interest in business processes to a new level of intensity. In this talk we consider some of the roots of today's interest in business process management (BPM), the growing resources available to those who want to undertake business process change, the emerging BPM systems that seem destined to transform businesses in the next decade, and the implications this transformation will have for those who work in the new generation of processoriented organizations. 